\title{
Ferrimonas senticii sp. nov., a novel gammaproteobacterium isolated from the mucus of a puffer fish caught in Kaneohe Bay, Hawai'i
}

\author{
Sonia Campbell, Renee M. Harada and Oing X. Li \\ Department of Molecular Biosciences and Bioengineering, University of Hawai'i at Manoa, \\ 1955 East West Road, Honolulu, HI 96822, USA
}

Correspondence

Qing X. Li

qingl@hawaii.edu

\begin{abstract}
A novel species, strain $\mathrm{P} 2 \mathrm{~S} 11^{\top}$, was isolated from the mucus of a puffer fish caught off the coast of Kaneohe Bay, O'ahu, Hawai'i. A phylogenetic analysis based on 16S rRNA gene sequences showed that the novel strain was most closely related to Ferrimonas marina DSM $16917^{\top}$ and Ferrimonas balearica DSM $9799^{\top}$ with $93.5 \%$ and $82.9 \%$ sequence similarities, respectively, which established the novel strain as belonging to the genus Ferrimonas. The strain formed off-white coloured colonies on marine agar and cells were Gram-negative, non-motile rods. $\mathrm{H}_{2} \mathrm{~S}$ was produced when strain $\mathrm{P} 2 \mathrm{~S} 11^{\top}$ was grown on TSI medium with added salt. Strain $\mathrm{P} 2 \mathrm{~S} 11^{\top}$ had a DNA G +C content of 54.9 mol\% and the dominant fatty acids were $C_{16: 1} \omega 9 c, C_{16: 0}$ and $\mathrm{C}_{17: 1} \omega 8 \mathrm{c}$. On the basis of this polyphasic study, strain $\mathrm{P} 2 \mathrm{~S} 11^{\top}$ (=ATCC BAA-1480 ${ }^{\top}=\mathrm{DSM}$ $18821^{\top}$ ) represents a novel species of the genus Ferrimonas, for which the name Ferrimonas senticii sp. nov. is proposed.
\end{abstract}

The puffer fish Arothron hispidus is commonly found in the warm tropical waters around the Hawaiian islands. Bacterial strain $\mathrm{P} 2 \mathrm{~S} 11^{\mathrm{T}}$ was isolated from the mucus of a specimen of $A$. hispidus that was caught off the windward side of the island of O'ahu in August 2005. Strain P2S11 ${ }^{\mathrm{T}}$ was isolated on half-strength marine agar 2216 (1/2 MA; Difco). The off-white colonies were further purified and maintained in 10\% glycerol: $90 \%$ half-strength marine broth at $-80{ }^{\circ} \mathrm{C}$.

The genus Ferrimonas was established in 1995 with the description of the type species Ferrimonas balearica (Rosselló-Mora et al., 1995). To date, three other species, Ferrimonas marina (Katsuta et al., 2005), Ferrimonas futtsuensis and Ferrimonas kyonanensis (Nakagawa et al., 2006), have been isolated, characterized and described.

The male puffer fish weighed $306 \mathrm{~g}$. It was dissected into separate organs and body parts. Subsamples of each organ, as well as 5-10 g samples of the mucus, were homogenized with sterile artificial seawater (50-100 ml; Coralife) and serial dilutions were plated onto ORI agar (Simidu \& Tsukamoto, 1985) and 1/2 MA (Difco). The media were incubated at $30^{\circ} \mathrm{C}$ for $1-5$ days. Genomic DNA was isolated from pure cultures using a phenol/chloroform mixture (Marmur, 1961). Amplification of the 16S rRNA gene from genomic DNA was performed by PCR using primers 27F and 1492R (Lane, 1991) and Mastermix Taq

The GenBank/EMBL/DDBJ accession numbers for the 16S rRNA and gyrB gene sequences of strain P2S11 ${ }^{\top}$ are DQ778094 and EF015634, respectively.
DNA polymerase (Eppendorf). Amplification of the gyrase subunit B gene ( $g y r B)$ was achieved using the UP1Ei and UP2ri primers as described in Katsuta et al. (2005). All PCR products were purified using the Ultraclean PCR purification kit (Mo Bio Lab) and sequenced by the Advanced Studies of Genomics, Proteomics and Bioinformatics Center at the University of Hawai'i at Manoa. For gyrB gene sequencing, a different set of primers was used from the amplification primers: UP1s and UP2rs were used as described in Katsuta et al. (2005). Sequences were edited manually and assembled using Seqman II (Lasergene) and subjected to a BLAST search for comparison with sequences in the public domain (Altschul et al., 1997). Sequence sizes were 1405 and 1063 bp for the 16S rRNA and gyrB genes, respectively.

The phylogenetic relationship of strain $\mathrm{P} 2 \mathrm{~S} 11^{\mathrm{T}}$ to other species of the genus Ferrimonas was determined based on comparative $16 \mathrm{~S}$ rRNA and gyrB gene sequence analyses. These analyses were performed with programs in the PHYLIP 3.63 package (Felsenstein, 2004). Pairwise similarities were calculated using CLUSTAL $\mathrm{W}$ multiple sequence alignment software (Chenna et al., 2003). Evolutionary distances were calculated by the maximum-likelihood method with DNADIST. Bootstrap analyses were based on 100 replicates using SEQBOOT, DNADIST and CONSENSE. Phylogenetic trees were constructed with jumbled orders of sequences and the neighbour-joining method (Saitou \& Nei, 1987).

Fig. 1 shows the phylogenetic trees based on the 16S rRNA (Fig. 1a) and gyrB (Fig. 1b) gene sequences. The 16S rRNA gene sequence of strain $\mathrm{P} 2 \mathrm{~S} 11^{\mathrm{T}}$ was most closely related to 
(a)

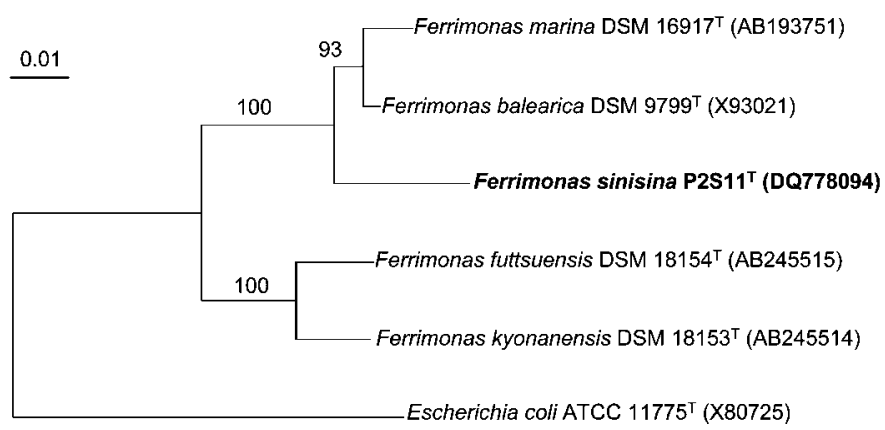

(b)

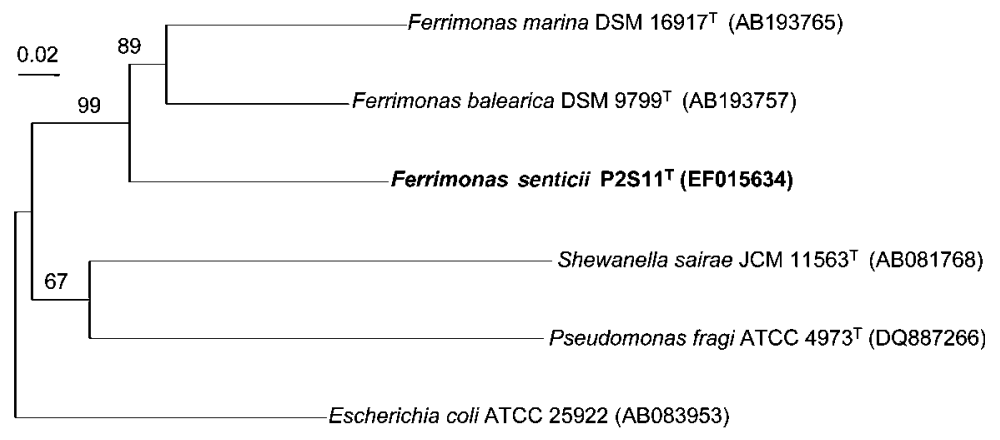

Fig. 1. Neighbour-joining trees based on the $16 \mathrm{~S}$ rRNA (a) and gyrB (b) gene sequences showing the relationships between strain $\mathrm{P} 2 \mathrm{~S} 11^{\top}$ and members of the genus Ferrimonas. Numbers at the nodes are bootstrap percentages based on the maximum-likelihood analysis of 100 resampled datasets. Escherichia coli strains ATCC $11775^{\top}$ and ATCC 25922 were used as the outgroups for the $16 S$ rRNA and gyrB gene trees, respectively. Bars, 0.01 nucleotide substitutions per site (a), 0.02 nucleotide substitutions per site (b). that of F. marina DSM $16917^{\mathrm{T}}$ (Katsuta et al., 2005) with $93.5 \%$ similarity. For the gyrB gene sequence, strain $\mathrm{P} 2 \mathrm{~S} 11^{\mathrm{T}}$ was most closely related to $F$. balearica DSM $9799^{\mathrm{T}}$ with $82.9 \%$ similarity (Rosselló-Mora et al., 1995). Based on these low sequence similarities $(<97 \%)$, strain $\mathrm{P} 2 \mathrm{~S} 11^{\mathrm{T}}$ should be considered distinct from other species of the genus Ferrimonas (Stackebrandt \& Goebel, 1994).

The DNA G $+\mathrm{C}$ content of strain $\mathrm{P} 2 \mathrm{~S} 11^{\mathrm{T}}$ was determined by the Deutsche Sammlung von Mikroorganismen und Zellkulturen (Braunschweig, Germany) using a HPLC method (Mesbah et al., 1989; Tamaoka \& Komagata, 1984). The DNA G+C content of strain $P 2 S 11^{\mathrm{T}}$ was $55 \mathrm{~mol} \%$, a value lower than that of all other species of the genus Ferrimonas, for which the DNA G $+\mathrm{C}$ content varies from 57 to $60 \mathrm{~mol} \%$. Fatty acid methyl ester analysis for strain $\mathrm{P} 2 \mathrm{~S} 11^{\mathrm{T}}$ was performed by MIDI Laboratories using whole cells grown on MA for $24 \mathrm{~h}$ at $28{ }^{\circ} \mathrm{C}$ (Sasser, 1997). The fatty acid content of strain $\mathrm{P} 2 \mathrm{~S} 11^{\mathrm{T}}$ and that of other species of the genus Ferrimonas that are available are summarized in Table 1 . The major fatty acids for $F$. balearica DSM $9799^{\mathrm{T}}$ and F. marina DSM $16917^{\mathrm{T}}$ were $\mathrm{C}_{18: 1} \omega 9 c$ (17.6 and $16.3 \%$, respectively), $\mathrm{C}_{16: 0}$ (13.4 and $13.9 \%$, respectively) and $\mathrm{C}_{15: 0}$ iso (9.8 and $11.5 \%$, respectively). The major fatty acids for $F$. futtsuensis FUT3661 ${ }^{\mathrm{T}}$ and F. kyonanensis Asr22-7 ${ }^{\mathrm{T}}$ were $\mathrm{C}_{16: 1} \omega 9 \mathrm{c}$ (20.4 and $28.5 \%$, respectively), $\mathrm{C}_{16: 0}$ (19.4 and $15.6 \%$, respectively) and $\mathrm{C}_{18: 1} \omega 9 c$ (15.9 and $10.9 \%$, respectively). For strain $\mathrm{P} 2 \mathrm{~S} 11^{\mathrm{T}}$, the main three fatty acids were $\mathrm{C}_{16: 1} \omega 9 \mathrm{c}$ $(16.9 \%), \mathrm{C}_{16: 0}(13.2 \%)$ and $\mathrm{C}_{17: 1} \omega 8 c(10.6 \%)$. Fatty acid $\mathrm{C}_{16: 1} \omega 9 c$ was not detected in the analysis of $F$. balearica and F. marina.
Quinone analysis was performed using fresh whole cells of strain $\mathrm{P} 2 \mathrm{~S} 11^{\mathrm{T}}$ grown in marine broth for 2-3 days. The cells were extracted using a mixture of chloroform/methanol (2:1, v/v; Hiraishi, 1988). After filtration and dilution in acetone, the extract was analysed by LC-MS using a HPLC (1100 series; Agilent) coupled to a diode array detector and a single quadrupole mass spectrometer (model SL; Agilent). The HPLC column used was a Vydac C18 Mass Spec column. The most abundant quinone found in F. balearica and F. marina was menaquinone MK7 (Rosselló-Mora et al., 1995; Katsuta et al., 2005), similar to F. futtsuensis and F. kyonanensis (Nakagawa et al., 2006). MK7 was also the most abundant menaquinone in strain $\mathrm{P} 2 \mathrm{~S} 11^{\mathrm{T}}$.

Cells of strain $\mathrm{P} 2 \mathrm{~S} 11^{\mathrm{T}}$ were Gram-negative rods and nonmotile. Motility was checked by the hanging drop method using light microscopy under a $100 \times$ objective with oil immersion and by stab inoculation into modified motility test agar $\left(1^{-1}: 10 \mathrm{~g}\right.$ tryptone, $20 \mathrm{~g} \mathrm{NaCl}$ and $5 \mathrm{~g}$ agar). After two days growth on MA at $30{ }^{\circ} \mathrm{C}$, cells were around $1.7 \mu \mathrm{m}$ in diameter. Salt was required for growth and the range of salt tolerance was $1.5-7.0 \%(\mathrm{w} / \mathrm{v})$, with an optimum value of $2.0 \%$. The cells grew within a temperature range of $20{ }^{\circ} \mathrm{C}$ (slow growth, $2-3$ days) to $37{ }^{\circ} \mathrm{C}$. The temperatures tested were $5,20,25,30,37$ and $42{ }^{\circ} \mathrm{C}$ on MA plates over 1 week. Other strains of the genus Ferrimonas are facultative anaerobes capable of $\mathrm{Fe}$ (III) reduction. Strain $\mathrm{P} 2 \mathrm{~S} 11^{\mathrm{T}}$ grew anaerobically on MA (in a Gas-Pak Pouch; $\mathrm{BD})$. The iron-reducing capability of strain $\mathrm{P} 2 \mathrm{~S} 11^{\mathrm{T}}$ was tested anaerobically with lactate and iron (III) citrate (Lovley \& Phillips, 1986), but the novel strain did not grow under these conditions. 
Table 1. Fatty acid content (\%) of species of the genus Ferrimonas

Taxa: 1, strain P2S11 ${ }^{\mathrm{T}}$; 2, F. marina DSM $16917^{\mathrm{T}}$ (Katsuta et al., 2005); 3, F. balearica DSM $9799^{\mathrm{T}}$ (Katsuta et al., 2005); 4, F. futtsuensis FUT3661 ${ }^{\mathrm{T}}$ (Nakagawa et al., 2006); 5, F. kyonanensis Asr22-7 $7^{\mathrm{T}}$ (Nakagawa et al., 2006). Taxon 1 was grown in marine broth for $24 \mathrm{~h}$ at $28{ }^{\circ} \mathrm{C}$, taxa 2 and 3 were grown in marine broth for $24 \mathrm{~h}$ at $25{ }^{\circ} \mathrm{C}$, and taxa 4 and 5 were grown in marine broth at $25{ }^{\circ} \mathrm{C}$. Only values greater than $0.99 \%$ are listed. ND, No data.

\begin{tabular}{|c|c|c|c|c|c|}
\hline Fatty acid & 1 & 2 & 3 & 4 & 5 \\
\hline$C_{12: 0}$ & 2.7 & ND & ND & 3.7 & 5.0 \\
\hline $\mathrm{C}_{13: 0}$ & 1.5 & ND & ND & ND & $\mathrm{ND}$ \\
\hline $\mathrm{C}_{12: 0} 3-\mathrm{OH}$ & 3.6 & ND & ND & 6.7 & 8.1 \\
\hline $\mathrm{C}_{14: 0}$ anteiso & ND & 1.2 & ND & ND & $\mathrm{ND}$ \\
\hline $\mathrm{C}_{14: 0}$ iso & 1.3 & ND & $\mathrm{ND}$ & ND & $\mathrm{ND}$ \\
\hline $\mathrm{C}_{14: 0}$ & 2.6 & ND & $\mathrm{ND}$ & 3.6 & 5.1 \\
\hline $\mathrm{C}_{15: 0}$ iso & 1.8 & 11.5 & 9.8 & 2.2 & 1.4 \\
\hline $\mathrm{C}_{15: 1} \omega 8 c$ & 2.1 & ND & ND & ND & ND \\
\hline $\mathrm{C}_{15: 0}$ & 3.2 & 2.1 & 1.8 & ND & ND \\
\hline $\mathrm{C}_{16: 0}$ iso & 1.3 & 2.8 & ND & $\mathrm{ND}$ & ND \\
\hline $\mathrm{C}_{16: 1}$ iso $\omega 9 c$ & ND & 7.0 & 10.4 & ND & $\mathrm{ND}$ \\
\hline $\mathrm{C}_{16: 1}$ iso $\omega 7 \mathrm{c}$ & ND & 6.3 & 5.2 & ND & ND \\
\hline $\mathrm{C}_{16: 1} \omega 9 c$ & 16.9 & ND & ND & 20.4 & 28.5 \\
\hline $\mathrm{C}_{16: 0}$ & 13.2 & 13.9 & 13.4 & 19.4 & 15.6 \\
\hline $\mathrm{C}_{17: 0}$ iso & 0.2 & 4.2 & 2.1 & ND & ND \\
\hline $\mathrm{C}_{17: 1} \omega 8 c$ & 10.6 & 7.3 & 12.6 & 2.2 & 1.8 \\
\hline $\mathrm{C}_{17: 1} \omega 6 c$ & 1.1 & ND & ND & ND & ND \\
\hline $\mathrm{C}_{17: 0}$ & 6.0 & 5.5 & 8.0 & ND & ND \\
\hline $\mathrm{C}_{18: 1} \omega 9 c$ & 9.8 & 16.3 & 17.6 & 15.9 & 10.9 \\
\hline $\mathrm{C}_{18: 1} \omega 7 c$ & 3.5 & 9.4 & 4.9 & 4.0 & 1.9 \\
\hline $\mathrm{C}_{18: 0}$ & 2.0 & 3.6 & 3.9 & 1.9 & $\mathrm{ND}$ \\
\hline \multicolumn{6}{|c|}{ Summed features ${ }^{\star}$} \\
\hline 1 & 2.6 & ND & ND & ND & ND \\
\hline 2 & 2.2 & ND & ND & ND & 3.3 \\
\hline 3 & 7.2 & ND & ND & 9.8 & 10.3 \\
\hline
\end{tabular}

* Summed feature 1 contains $\mathrm{C}_{15: 1}$ iso $\mathrm{H}$ and/or $\mathrm{C}_{13: 0}$ 3-OH; summed feature 2 contains $\mathrm{C}_{16: 1}$ iso $\mathrm{I}$ and/or $\mathrm{C}_{14: 0} 3-\mathrm{OH}$; summed feature 3 contains $\mathrm{C}_{16: 1} \omega 7 c$ and/or $\mathrm{C}_{16: 1} \omega 6 c$ and/or $\mathrm{C}_{15: 0}$ iso $2-\mathrm{OH}$.

Physiological and biochemical tests performed are summarized in Table 2. The presence or absence of constitutive enzymes was determined using API ZYM (bioMérieux) and the profile of substrates utilized was obtained with API 20NE (bioMérieux). The oxidation of carbon substrates was determined with Biolog GN microplates (Table 2). Hydrogen sulfide production was tested with modified triple-sugar iron (TSI) agar slants (EMD). Since TSI contains only $0.5 \% \mathrm{NaCl}, 2 \% \mathrm{NaCl}(\mathrm{w} / \mathrm{v})$ was added to the medium for optimal growth. The TSI tubes were incubated at $30{ }^{\circ} \mathrm{C}$. After $24 \mathrm{~h}$, a black precipitate indicating the presence of $\mathrm{H}_{2} \mathrm{~S}$ was observed. No fermentation occurred. In comparison, F. marina does not produce $\mathrm{H}_{2} \mathrm{~S}$ and $F$. balearica does.
Table 2. Characteristics of species of the genus Ferrimonas

Taxa: 1, strain $\mathrm{P} 2 \mathrm{~S} 11^{\mathrm{T}}$; 2, F. marina DSM $16917^{\mathrm{T}}$ (Katsuta et al., 2005); 3, F. balearica DSM 9799 ${ }^{\mathrm{T}}$ (Katsuta et al., 2005), 4, F. futtsuensis FUT3661 ${ }^{\mathrm{T}}$ (Nakagawa et al., 2006); 5, F. kyonanensis Asr22-7 $7^{\mathrm{T}}$ (Nakagawa et al., 2006). ND, No data.

\begin{tabular}{|lccccc|}
\hline Characteristic & $\mathbf{1}$ & $\mathbf{2}$ & $\mathbf{3}$ & $\mathbf{4}$ & $\mathbf{5}$ \\
\hline Growth at $42^{\circ} \mathrm{C}$ & - & - & + & - & - \\
Growth in $\mathrm{NaCl}$ at $(\%, \mathrm{v} / \mathrm{v}):$ & & & & & \\
0.5 & - & - & + & - & - \\
5.5 & + & - & + & - & - \\
$\mathrm{H}_{2} \mathrm{~S}$ production & + & - & + & + & + \\
Urease & - & - & - & $\mathrm{ND}$ & $\mathrm{ND}$ \\
$\mathrm{Fe}(\mathrm{III})$ reduction & - & - & + & + & + \\
Biolog profile: & & & & & \\
$\quad$ Acetate & + & + & + & - & - \\
L-Alanyl glycine & - & + & - & $\mathrm{ND}$ & $\mathrm{ND}$ \\
$\quad$ Dextrin & - & + & - & $\mathrm{ND}$ & $\mathrm{ND}$ \\
$\quad \mathrm{D}-$ Glucose & - & + & - & - & - \\
$\quad$ L-Glutamate & - & + & + & - & - \\
Lactate & + & + & + & + & + \\
$\quad$ Maltose & - & + & + & - & - \\
DNA G+C content $(\mathrm{mol} \%)$ & 55 & 60 & 60 & 58 & 57 \\
& & & & & \\
\hline
\end{tabular}

On the basis of the distinct $16 \mathrm{~S}$ rRNA and gyrB gene sequences, physiology and fatty acid composition, strain $\mathrm{P} 2 \mathrm{~S} 11^{\mathrm{T}}$ represents a novel species of the genus Ferrimonas, for which the name Ferrimonas senticii sp. nov. is proposed.

\section{Description of Ferrimonas senticii sp. nov.}

Ferrimonas senticii (sen.ti.ci.i. N.L. gen. n. senticii of Sentic, named in honour of Sinisa Sentic for scientific and philosophical discussions).

Aerobic, facultatively anaerobic. Off-white colonies. Gramnegative rods, cell size around $1.7 \mu \mathrm{m}$ in length and nonmotile. Circular colonies form on $\mathrm{MA}$ at $30{ }^{\circ} \mathrm{C}$ after $1-$ 2 days. Optimum temperature range is $20-37^{\circ} \mathrm{C}$. $\mathrm{NaCl}$ is required for growth in a range of $1.7-7.0 \%(\mathrm{w} / \mathrm{v})$, with an optimum at $2.0 \%$. Strain $\mathrm{P} 2 \mathrm{~S} 11^{\mathrm{T}}$ utilizes DL-lactic acid, acetic acid, Tween 80, inosine, uridine, thymidine and pyruvic acid methyl ester as carbon sources in the Biolog GN2 test. Produces $\mathrm{H}_{2} \mathrm{~S}$ on TSI $+2 \% \mathrm{NaCl}$ agar. The DNA $\mathrm{G}+\mathrm{C}$ content is $54.9 \mathrm{~mol} \%$. The predominant fatty acids are $\mathrm{C}_{16: 1} \omega 9 c, \mathrm{C}_{16: 0}$ and $\mathrm{C}_{17: 1} \omega 8 c$.

The type strain, P2S $11^{\mathrm{T}} \quad\left(=\mathrm{ATCC}\right.$ BAA $-1480^{\mathrm{T}}=\mathrm{DSM}$ $18821^{\mathrm{T}}$ ), was isolated from the slime of a puffer fish, Arothron hispidus, caught off the coast of the windward side of the island of O'ahu, Hawai'i.

\section{Acknowledgements}

This work was supported in part by a contractual agreement with the State of Hawai'i Department of Health - Office of Hazard Evaluation and Emergency Response. We thank Brian and Myrna Yamane for sample collection. 


\section{References}

Altschul, S. F., Madden, T. L., Schaffer, A. A., Zhang, J., Zhang, Z., Miller, W. \& Lipman, D. J. (1997). Gapped BLAST and PSI-BLAST: a new generation of protein database search programs. Nucleic Acids Res 25, 3389-3402.

Chenna, R., Sugawara, H., Koike, T., Lopez, R., Gibson, T. J., Higgins, D. G. \& Thompson, J. D. (2003). Multiple sequence alignment with the CLUSTAL series of programs. Nucleic Acids Res 31, 3497-3500.

Felsenstein, J. (2004). PHYLIP (phylogeny inference package), version 3.63. Distributed by the author. Department of Genome Sciences, University of Washington, Seattle, USA.

Hiraishi, A. (1988). Respiratory quinone profiles as tools for identifying different bacterial populations in activated sludge. J Gen Appl Microbiol 34, 39-56.

Katsuta, A., Adachi, K., Matsuda, S., Shizuri, Y. \& Kasai, H. (2005). Ferrimonas marina sp. nov. Int J Syst Evol Microbiol 55, 1851-1855.

Lane, D. J. (1991). 16S/23S rRNA sequencing. In Nucleic Acid Techniques in Bacterial Systematics, pp. 115-175. Edited by E. Stackebrandt \& M. Goodfellow. Chichester: Wiley.

Lovley, D. R. \& Phillips, E. J. (1986). Organic matter mineralization with reduction of ferric iron in anaerobic sediments. Appl Environ Microbiol 51, 683-689.

Marmur, J. (1961). A procedure for the isolation of deoxyribonucleic acid from microorganisms. J Mol Biol 3, 208-218.
Mesbah, M., Premachandran, U. \& Whitman, W. B. (1989). Precise measurement of the $\mathrm{G}+\mathrm{C}$ content of deoxyribonucleic acid by highperformance liquid chromatography. Int J Syst Bacteriol 39, 159-167.

Nakagawa, T., lino, T., Suzuki, K. \& Harayama, S. (2006). Ferrimonas futtsuensis sp. nov. and Ferrimonas kyonanensis sp. nov., selenatereducing bacteria belonging to the Gammaproteobacteria isolated from Tokyo Bay. Int J Syst Evol Microbiol 56, 2639-2645.

Rosselló-Mora, R. A., Ludwig, W., Kämpfer, P., Amann, R. \& Schleifer, K.-H. (1995). Ferrimonas balearica gen. nov., spec. nov., a new marine facultative $\mathrm{Fe}(\mathrm{III})$-reducing bacterium. Syst Appl Microbiol 18, 196-202.

Saitou, N. \& Nei, M. (1987). The neighbor-joining method: a new method for reconstructing phylogenetic trees. Mol Biol Evol 4, 406-425.

Sasser, M. (1997). Identification of bacteria by gas chromatography of cellular fatty acids, MIDI Technical Note 101. Newark, DE: MIDI Inc.

Simidu, U. \& Tsukamoto, K. (1985). Habitat segregation and biochemical activities of marine members of the family Vibrionaceae. Appl Environ Microbiol 50, 781-790.

Stackebrandt, E. \& Goebel, B. M. (1994). Taxonomic note: a place for DNA-DNA reassociation and $16 \mathrm{~S}$ rRNA sequence analysis in the present species definition in bacteriology. Int J Syst Bacteriol 44, 846-849.

Tamaoka, J. \& Komagata, K. (1984). Determination of DNA base composition by reversed-phase high-performance liquid chromatography. FEMS Microbiol Lett 25, 125-128. 